\title{
Technology For The Techies - Student Engagement in a Language Class
}

\author{
K. Madhuri and Devidutta Das \\ BVRIT Hyderabad College of Engineering for Women, Hyderabad, India
}

\section{ABSTRACT}

When the Pandemic threatened to bring the whole teaching learning scenario to a complete halt, technology with all its might came to the rescue. Transition from physical classrooms to the virtual mode was not an easy one. Learners who were always fiddling with gadgets to be active on social media and gaming were asked to continue learning through the same gadgets. The pedagogical structure changed its form as the role of a teacher changed to a facilitator. Content delivery for virtual mode needed strategic planning, which involved students' participation. As it is believed that the ratio of teacher talk to that of student talk should be of 20:80, to overcome the psychological barrier, lesson plan was developed with the scope for the pupils to be self-motivated by participating in brainstorming sessions, online polls, vocabulary games, quizzes, word webs etc. This paper will concentrate on the teaching-learning structure which involves the different online tools of teaching used to smoothen the process.

\section{KEY WORDS: ONLINE ACTIVITIES, STUDENT ENGAGEMENT, INTERACTIVE LESSON PLAN, STUDENT MOTIVATION.}

\section{INTRODUCTION}

\section{Objectives}

- To understand the need of technical students in English Language virtual class room.

- To understand the need of pedagogical shift in English Language virtual class room for engineering students.

- To plan content and teaching learning process according to the needs of engineering students in this digital transformation of education process.

- $\quad$ To explore various ways to use online tools to keep learners engaged and motivated.

The Pandemic of COVID 19 was the unprecedented event that threatened to cripple the world from all quarters. While the virus brought everything to a halt, the education sector was something that was mightily affected by the virus. Books replaced phones, tablets and laptops. The teacher turned into a virtual facilitator teaching subjects with the help of online materials, ppts and videos. Though

Biosc Biotech Res Comm P-ISSN: 0974-6455 E-ISSN: 2321-4007

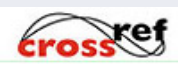

Identifiers and Pagination

Year: 2021 Vol: 14 No (8) Special Issue

Pages: 162-164

This is an open access article under Creative

Commons License Attribn 4.0 Intl (CC-BY). DOI: http://dx.doi.org/10.21786/bbrc/14.8.37

the sudden change did offer many difficulties, it opened up a new vista of online learning which was till then shrouded in oblivion. The challenges were immense but the new ways and opportunities were even bigger. This time provided an opportunity for the educational institution to fortify their technological infrastructure. Government of India also took many initiatives for the benefit of the students and the teachers by providing access to many online libraries and MOOC courses like SWAYAM, NPTEL, NASSCOM etc. Accessibility to foreign courses offered by foreign universities through edutech platforms like COURSERA etc. As English teachers of an engineering college, it was difficult for us to cope with the change but nonetheless internet helped us to learn the tricks of the trade in a much smoother way. A whole new virtual world with Kahoot, Quizizz, Padlet etc. saved our days.

Pedagogical Shift From Keats To Kahoot: For an English teacher the pedagogical structure is never restricted to using only a chalk and duster it involves weaving together stories, anecdotes and many other ways with a deep personal touch. It is a part of Humanities which seeks to "irrigate the deserts that our lives have already become" (C. S. Lewis). In spite of the onslaught of the virtual tools, English teachers are doing a fabulous job by melding the world of English with the virtual world. The use of virtual tools in the engineering colleges was restricted to language laboratories but with the pandemic,

Article Information

Received: $09^{\text {th }}$ June 2021 ccepted after revision: $29^{\text {th }}$ July 2021 
the rules of the game changed and different kinds of experimentations began. The online mode brought about many innovative tactics which were earlier not even thought of.

Interactive Lesson Plan: English language teaching in Indian classrooms has undergone various changes since the period of introduction of English language as a second language in Indian education system. Different approaches and methods were adopted in due course of time to include English in the academic structure. Covid situation enabled all institutions to think about learning outside of the traditional class model. It opened ways for many new challenges in classroom itself for the young techies, and even for the facilitators to train them for the upcoming challenges in new normal. Though the pedagogical shift with digital transformation was inevitable for the whole educational process in these unprecedented times, the alarming factor was "How to plan and organize virtual class room interaction?”.

Though it was understood that making use of available online tools and resources for teaching learning process can be continued, the concept of understanding the needs of the learner and planning accordingly to achieve the goal of attaining objectives and course outcomes at end of transacting the content was the real challenge. To address the needs of students for the virtual class, content was divided according to the intellectual levels of the students while attending online classes. Interactive lesson plans were designed for our students to keep them involved. Lesson-plan for virtual class room is divided with segments like -brainstorm session, introduction of the content, student interaction and recapitulation. Online tools were used for every aspect of the class interaction.

Student Engagement and Online Activities: Content was introduced with a brainstorming session to enable students to connect themselves with their previous knowledge of the concept, for which online tools like "Answer Garden", "Socrative" "Padlet" etc., were used. With help of these tools students were asked to answer the question posted before them and screen could be shared and made visible for whole class. All the answers given by individual learner were be displayed on the page. "Answer Garden" is a visually appealing tool where the answers look like a bunch of flowers clubbed together. Even the simple google chat or the Microsoft teams chat box were also used to elicit answers from the students thus ensuring their participation in the classroom. These tools motivated the students by making them feel connected to their peer group and shedding the feeling of alienation which often hounds participants in an online class.

Teachers doled out the content with help of various online resources like You tube videos as well as videos created by the faculty members using various online tools like 'Screencast-o-matic',Flipgrid', 'Screen-o--matic', 'Presentation Tube', various online language sites, online language groups. Even some teachers "created videos and podcasts as well as interactive flowcharts, screencasts, and Voice Threads. Students appreciated instructors who understood that the web is an audiovisual medium and were willing to put the time into creating content that fits the medium rather than simply transcribing their face-toface lectures into long text documents" (Orlando).These efforts were deemed important as they were thought to improve various language skills like Listening, Speaking, Reading and Writing.

Online tools like 'One Note',Microsoft White Board' allowed students to write and participate in ongoing teaching process as they used to do in physical classes. Various LMS portals and platforms like Zoom, Microsoft Teams, Google Meet, provided various options like "break out rooms" for learners to continue discussion in groups and to use academic language to ask questions and explain, elaborate on, and discuss complex ideas. Some of the teachers in the western countries used "escape rooms" for teach concepts to the students. Students would be virtually locked inside the "escape rooms" and they were supposed to find their way out by solving puzzles in the "escape rooms". Students were collaboratively worked to solve various puzzle thus giving a fillip to their teamsmanship. Language games using online tools like Quizzes, Kahoot, Quizlet, Google forms acted as catalyst to keep the class lively by enabling students to participate in the ongoing virtual classes. Immediate score displayed and active participation by peers motivate other students also to participate actively. Vocabulary enhancing tools and websites like Dictionary .com, Word Web, Visuwords, Thesarus.com, onelook.com, editorial words.com helped students to learn new vocabulary and use them in real life contexts.

Learner Motivation: Apart from regular course work learners were asked to meet virtually to take part in a debate, group discussion, Jam sessions, book reviews and present their opinions. News reading was also majorly followed so to motivate learners to improve their reading and speaking skills alive and improve them even in the virtual mode. Activities like report writing, travelogue writing, resume writing, essay writing etc., and submitting them online through Whatsapp, email, Google Classroom" motivated students to be active and explore more language than in physical classes. As online resources are available abundantly to the learners. Government initiatives to keep all the online resources accessible to the learners in various platforms like NPTEL-SWAYAM, National Digital Library etc., and edutech platforms like Coursera, Edx enable learners to explore various articles and courses from international universities to enhance their language skills.

Apart from these activities and resources assessment and feedback also motivates student to be activity in online classes. Day to day formative assessments conducted by using google forms, feedback collected by using online polls like Mentimeter etc., helped academicians to modify and change strategies in creating content for virtual needs, planning time table, student involvement and interaction, continuous scope for students to practice 
LSRW skills. Learners were enabled to explore websites like "Cambridge English.org" to test their language skills LSRW individually. Practicing with the sample activities given online for free and testing their improvement in each skill motivated them and improve language as per the need of the market. These online resources played major role in improving communicative English in engineering graduates to meet the challenges across the world.

Findings And Suggestions: With the implementation of the teaching learning strategies according to needs and suitability of online mode, $85 \%$ of learners felt motivated with inclusion of online activities and tools for brainstorming session. 75\% of learners felt introducing various activities apart from the course work as mentioned above enabled them to overcome the hindrances in usage of language on digital platforms. These activities and presentation skills practice in online mode helped and boosted the confidence of most of the students appearing for virtual interviews in this pandemic time. Engineering graduates especially whose grooming towards communicative aspect of language was at stake due to pandemic, stated that inclusion of various online activities in the virtual mode of teaching helped them to overcome this state and face interviews and other career challenges successfully.

\section{CONCLUSION}

English language teaching threw many challenges to the teachers in engineering colleges. The teachers did not get daunted by the changes. They tirelessly worked to make their students proficient in Communicative English which could help them to get a foothold in the global market. The new normal brought a shift in teaching learning process from physical classes to virtual classes. Thus, role of the teacher changed from teaching to facilitating the students to face the challenges globally. Smart usage and adaptation of upcoming technological advancement and integrating available resources to teaching learning process will enhance learning in online mode.

\section{REFERENCES}

https://www.teachingprofessor.com/topics/teachingstrategies/group-work/escape-rooms-for-increasedstudent-engagement/

https://www.teachingprofessor.com/topics/covid-19/ reflecting-on-effective-teaching-strategies-facultyshare-their-successes/

https://www.teachingprofessor.com/topics/for-thosewho-teach/looking-for-learning-in-the-transition-toonline-courses/

https://www.teachingprofessor.com/topics/covid-19/ trauma-informed-teaching-during-the-transitionto-virtualized-learning-and-in-response-to-thecoronavirus-pandemic/

Jena, Dr. Pravat Kumar, (2020), Impact of Covid 19 on Education in India, International Journal of Current Research, 12, (07), 12582-12586 